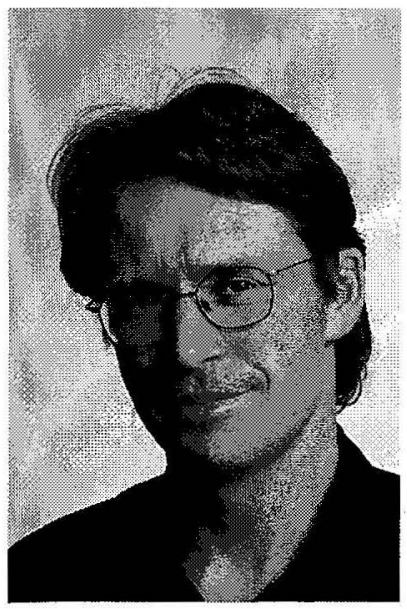

\title{
TRIPLE JEOPARDY: AGE, WORK AND THE INVISIBILITY OF MATURE JOB-SEEKERS IN NEW ZEALAND
}

\section{Lance Gray and Professor Judy McGregor}

Department of Communication and Journalism

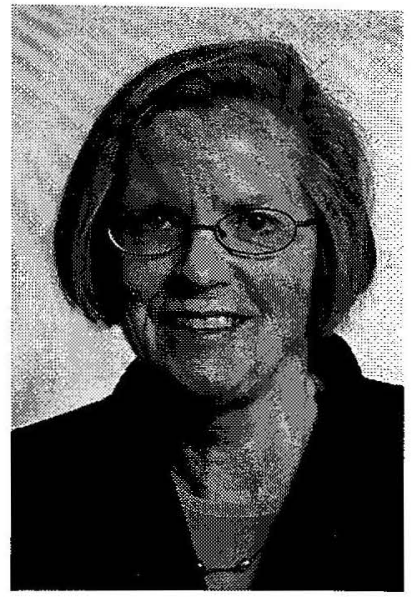

Massey University

\begin{abstract}
Youth has for so long dominated our thinking about employment that political and policy responses and societal debate about the value of older workers has been stifled. Yet the urgency of population ageing in New Zealand at a time of projected labour shortages means older workers must urgently become a policy priority. Latest projections indicate that the population aged 65 years and over is expected to grow by about 100,000 during the current decade to reach 552,000 by 2011. And by 2051 there are projected to be at least 60 percent more elderly than children (Statistics New Zealand, 2000). The threat of future labour shortages has been raised by numerous authors (Callister and Rose, 2001; Stephenson and Scobie, 2002; and the New Zealand Institute of Economic Research, 2002) with the older worker viewed implicitly as part of the problem. The paper reports on the largest contemporary study of mature job-seekers undertaken recently in New Zealand. It explores the job search efforts and behaviour of mature job seekers and the implications for policy intervention. The study also poignantly reveals the hidden personal and community costs of discrimination and unemployment amongst older people. The implications of framing employment as a youth concern only and the significance of disadvantaged older workers and job seekers is discussed. Finally the paper addresses the question of "what responsibility does society have towards skilled and unskilled older workers?"
\end{abstract}

\section{Introduction}

The older worker has received little attention in New Zealand with domestic publications barely addressing the issue beyond the statutory requirements of the Human Rights Act 1993 (Macky and Johnson, 2000; Rudman, 2000; Deeks Parker and Ryan, 1994); while Sayers and Tremaine's (1994) New Zealand equal employment opportunities (EEO) text omits the older worker entirely. In the wider debate the arguably more topical issues of health services and retirement income have subsumed the issue of employment for older people. For example, Koopman-Boyden's (1992) "New Zealand's Ageing Society" devotes a single page to "The elderly at work" while more recently with the Government's "The New Zealand Positive Ageing Strategy" (Dalziel, 2001) employment of the older worker issues are again a distinctly lesser priority than retirement and health.

Of some encouragement is that one of the ten points of action in the Government's positive ageing strategy was the "elimination of ageism in the workforce, and the promotion of flexible employment options for older people" (Dalziel, 2001, p.30). The issue of unemployment for the New Zealand older worker has received even less interest amongst policy makers given the almost implicit assumption that unemployment is primarily a "youth" issue (The Royal Commission on Social Policy, 1988; Shirley, Easton, Briar and Chatterjee, 1990; Higgins, 1999). Why then have issues surrounding older workers become significant?

New Zealand has undergone dramatic change to its economy over the past few decades with few prepared for the consequences of the election of a Labour government in 1984. The outcome of these changes for the labour market, in particular, are not in doubt with greater disparities between low and high-income earners, skilled and unskilled workers, greater marginalisation of women, Maori and Pacific Island peoples, and more recently older workers (Easton, 1997; Kelsey 1999).

It was during this period that long-term unemployment also began to impact upon older workers; though with little attention as youth long-term unemployment was just as bad (Department of Labour, 1989). Previously longterm unemployment had either been lower for older workers or shared evenly across age cohorts. Now the greatest proportions of long-term unemployed were to be found amongst older unskilled men in particular (Statistics New Zealand, 2002; Treasury, 2001). 


\section{History of older workers in New Zealand}

The issue of unemployment for older workers has always been of significant historical interest because it was the concern with the welfare of older (male) workers that lead to one of New Zealand's significant pieces of welfare legislation. Thomson (1998) in his examination of the circumstances leading up to New Zealand's introduction of tax-funded non-contributory old age pensions in 1898 describes a colonial population that had suddenly aged with numbers doubling each decade to pass four in 100 of all persons by century's end which occasioned much anxiety about a loss of New World energy. A similar anxiety is presently afflicting economists; one group is already convinced that an older workforce will be less productive (New Zealand Institute of Economic Research, 2002), while Treasury (Stephenson and Scobie, 2002) are more circumspect about the possible impacts upon worker productivity and management of the workforce.

\section{Population ageing in New Zealand}

Between 1901 and 1951, the number of New Zealanders aged 65 years and over increased almost six-fold, from 31,000 to 177,000 . Over the next 48 years this cohort grew by another 151 percent to reach 446,000 in 1999. This was much faster than for the rest of the population with the number of children under 15 years of age and those in the traditional working ages (15-64), increased by 54 and 109 percent respectively. A newborn male can now expect to live on average 74 years and a newborn female about 80 years. The elderly's share of New Zealand's population has trebled from 4 percent in 1901 to 12 percent in 1999.

Latest projections indicate that the population aged 65 years and over is expected to grow by about 100,000 during the current decade to reach 552,000 by 2011 . The pace of increase is expected to pick up after the year 2011, when the large baby boom generation begins to enter this age group. For instance between 2011 and 2021 the elderly population is expected to grow by about 200,000 and in the following ten years by 230,000 . By 2051 , there will be over 1.14 million people aged 65 years and over in New Zealand. They are expected to make up 25.5 percent (or 1 in every 4) of all New Zealanders (4.49 million). At present there are about half as many elderly New Zealanders as there are children. By 2051 there are projected to be at least 60 percent more elderly than children (Statistics New Zealand, 2000).

Of more immediate significance is that between 1946 and 1965 , New Zealand experienced a "baby boom" in which 1.125 million babies were born (Statistics New Zealand, 1995). This cohort today [2002] is aged between 35 and 55 years of age, which means for most, they are presently in the prime of their working life. In ten years time the entire baby boomer cohort will be termed older workers given either the OECD (2000) definition of an older worker 55 years and over, or Warr's (1994) accepted academic definition of 45 years and over.

\section{Government policy and older workers}

The current Government's policy approach to employment, and mature job-seekers in particular, is outlined in primarily three documents: (1) "Opportunity, Capacity, Participation: Government Employment Strategy 2000" (Maharey, 2000a); (2) "Pathways to Opportunity: From Social Welfare to Social Development" (Maharey, 2001), and (3) "The New Zealand Positive Ageing Strategy" (Dalziel, 2001). While relevant, the Ministry of Economic Development's (2000) "Regional Development Strategy" only indirectly discusses possible impacts on employment though it does attend to the regions that have been identified as being disadvantaged.

Of the six goals identified in the Employment Strategy, number six appears the most relevant to mature jobseekers. This goal states: Improving participation for people with disability and other groups at risk of longterm and persistent unemployment. Significantly, the only direct mention of older workers is in Appendix 2: Initiatives related to the employment strategy. Here Maharey (2000a, p.19) states:

The positive ageing strategy will include policies aimed at improving attitudes toward older workers and recognising the skills they can contribute in the workplace.

This point is significant because while New Zealand mature job-seeker concerns regarding long-term unemployment have been noted elsewhere (for e.g., Department of Labour, 1989; Tweedy and Johnson, 1996; McGregor and Gray, 2001); only in a speech by Dalziel (2001a) and finally by Maharey (2002a), both following the October release of McGregor and Gray's (2001) Mature Job-Seekers in New Zealand, have the concerns of mature job-seekers been directly addressed by government ministers.

For example, Dalziel's (2001) Positive Ageing Strategy shows its priorities by placing employment issues at number nine of the ten listed goals. The goal being "the elimination of ageism and the promotion of flexible work options" (p.22). For mature job-seekers the elimination of ageism would be a helpful attitudinal shift and current societal stereotypes are of little immediate help in getting a job. Responses from employers (McGregor, 2001) suggest flexible work options are not currently a focus compared to other human resource issues such as performance management of older workers (New Zealand Employers' Federation, 1998). The Positive Ageing Strategy's greater focus is health and retirement even though Dalziel (2001a) appears to have warmed to the older worker issue with a significant expansion in the attention given in a speech to the positive ageing forum when she notes: 
The significant impact that unemployment within ten years of retirement has on the quality of life in retirement. This indicates the importance of employment policies aimed at retaining older workers; and, perhaps most importantly the growing number of older people increases the importance of providing opportunities for their skills and experience to be utilised (p.2-3).

Similarly, Maharey (2002a) suggested to the Weekend Herald newspaper that job subsidies were likely to be among new policies to get job-seekers aged over 40 back to work. The significance of this proposal by Maharey cannot be underestimated because an examination of government press releases, speeches and policies during the term of the present government rarely mentions the issue of mature job-seekers.

One example obtained, is from a speech delivered to the Annual General Meeting of the Manawatu branch of the Mature Employment Support Agency where Maharey (2000b) says:

The Government accepts that the issues faced by mature workers have not been given sufficient attention in the past and we made a commitment in our pre-election policy to addressing those issues (p. 1)

Given that 2002 was an election year it is noteworthy after Maharey's previous promises of action, that he also had this to say to Employment Commissioner Ray Smith (Maharey, 2002, A5):

I don't want more pilots. I don't want more thinking. I just want to be able to say to mature workers... yes, things have got better.

How can things get better and what can be learned from the mature job-seeker study?

\section{The mature job-seeker study}

The experiences and aspirations of mature job-seekers have been under-researched by comparison with unemployed young people. This research, a survey of mature job-seekers aimed to address this research imbalance in the New Zealand context. The information provided by this research on mature job-seekers complements the growing picture we have of older workers in New Zealand. It comes at a time of increasing international and national interest in policy initiatives about positive ageing and older workers, and about the utilisation of human capital regardless of age. It follows two other surveys conducted by Massey University researchers in the past three years. These are:

1) a survey resulting in 2137 older worker respondents (54\% response rate) aged 55 years and over who were members of the Engineering, Printing and Manufacturing Union (EPMU).
2) a survey resulting in 1012 employer respondents (49\% response rate) through the New Zealand Employers' Federation (NZEF).

The high response rates of both these surveys reflects crucially two issues: 1) the partnership approach taken with both the EPMU and the NZEF and 2) the salience of older workers presently (McGregor, 2001).

\section{The present study}

The research sample consisted of 954 mature job-seekers who joined Mature Employment Support Agencies (MESA) in four regional cities: Whangarei, Palmerston North, Christchurch and Invercargill. Copies of a questionnaire survey, "Mature Job-Seeker Survey" were distributed to these agencies for administration with their members. The data was collected over a six month period to 31 May 2001 and involved the voluntary participation of job-seekers.

The information sheet that accompanied the survey invited job-seekers to participate and indicated that the survey aimed to help groups like MESA who were working with older unemployed people, improve public understanding of the barriers faced by mature job-seekers and help guide future policy about the employment of older workers. Participants were told that MESA staff on behalf of Massey University would administer the survey.

This approach had the advantage of sampling older people who through presenting themselves at a MESA office or who were registered with MESA could reasonably be viewed as active job-seekers. Given the statistics that show many older workers and job-seekers exit the labour market at age 55 and over, it was important that the survey tried to focus on older people seeking work rather than older workers without jobs who were effectively retired.

\section{Results}

The results presented here represent a "snapshot" of the greater mature job-seeker study and are used to illustrate particular issues that not only affect mature job-seekers but older workers generally. The paper covers findings relating to age, gender and job search effort. 
Table 1 shows that the majority of women respondents using MESA services are significantly younger than the men, with the 40-45 cohort representing the largest grouping of mature women job-seekers. This finding shows that many women returning to the workforce see MESA as one mechanism for supporting their return. This finding also provides support for the idea that women firmly see themselves as mature job seekers compared with their peers in the labour market, which confirms that some definitions of mature job seekers or older workers are "too restrictive".

Table 1 Age and gender

\begin{tabular}{lrrrrrr}
\hline \multicolumn{1}{c}{ Age } & \multicolumn{1}{c}{ Male } & \multicolumn{1}{c}{$\%$} & \multicolumn{1}{c}{ Female } & \multicolumn{1}{l}{ \% } & \multicolumn{1}{c}{ Total } & \multicolumn{1}{l}{$\%$} \\
\hline $\mathbf{4 0 - 4 5}$ & 71 & 8.2 & 137 & 15.8 & 208 & 24.0 \\
$\mathbf{4 6 - 5 0}$ & 73 & 8.4 & 109 & 12.6 & 182 & 21.0 \\
$\mathbf{5 1 - 5 5}$ & 138 & 15.9 & 111 & 12.8 & 249 & 28.7 \\
$\mathbf{5 6 - 6 0}$ & 98 & 11.3 & 51 & 5.9 & 149 & 17.2 \\
$\mathbf{6 1 - 6 5}$ & 46 & 5.3 & 16 & 1.8 & 62 & 7.1 \\
$\mathbf{6 6 - 7 0}$ & 5 & .6 & 7 & .8 & 12 & 1.4 \\
$\mathbf{7 1 - 7 5}$ & 2 & .2 & 2 & .2 & 4 & .5 \\
$\mathbf{7 6 +}$ & & & 2 & .2 & 2 & .2 \\
Total & $\mathbf{4 3 3}$ & $\mathbf{4 9 . 9}$ & $\mathbf{4 3 5}$ & $\mathbf{5 0 . 1}$ & $\mathbf{8 6 8}$ & $\mathbf{1 0 0 . 0}$ \\
\end{tabular}

*Missing variables are due to non-response by some respondents.

With regard to men, their responses peak in the 51-55 cohort which is still some ten to fifteen years away from New Zealand government funded superannuation; a period where savings are supposed to accumulate for the ever increasing life beyond the traditional retirement age of 65 years. In comparison to women this will represent, for many, the end of a largely unbroken period of continuous employment. The majority of these men are the victims of involuntary job loss (see Table 3) and represent a particularly vulnerable employment group (Treasury, 2001).

As proposed by Callister and Rose (2001) we are likely to see the opposite of what has been occurring since World War II where labour force participation rates for men, especially, have been decreasing in response to greater economic growth and therefore the ability to retire earlier. This will have the likely effect of giving older workers greater exposure with regard to employment issues. Presently older worker issues appears as a 'fringe' topic wheeled out every now and then with little real policy change occurring as a result (for example, Watkin, 2002 and Gill, 2002).

\section{Table 2 Job-search effort}

\begin{tabular}{lcrr}
\hline Time out of work & Mean Job-Search & S & \multicolumn{1}{c}{ Std. Dev } \\
\hline Less than a month & 4.01 & 92 & 2.13 \\
One to three months & 4.66 & 83 & 2.16 \\
Six months & 4.76 & 94 & 2.29 \\
One Year & 3.94 & 109 & 1.87 \\
Two years & 4.22 & 71 & 2.36 \\
Three years & 3.42 & 45 & 2.20 \\
Four years & 3.29 & 24 & 1.78 \\
Five years & 3.28 & 39 & 2.05 \\
Longer & 3.37 & 56 & 1.74 \\
Total & $\mathbf{4 . 0 5}$ & $\mathbf{6 1 3}$ & $\mathbf{2 . 1 5}$ \\
\hline
\end{tabular}

The first four to six months are critical to the success of mature job-seekers re-entering the labour market (see Table 2). The primary mean differences were between six months out of work against three, four, five years and longer. This statistic merely confirms that at six months job-search reaches its peak with an observed drop-off, as expected, through three, four, five years and longer: a point supported by other researchers (Feather, 1982; Kaufman, 1982; Warr and Jackson, 1984; Kulik, 2001).

This is also a clear indication that the New Zealand policy intervention to help mature job-seekers is best concentrated in the first six months after older workers exit the labour market. While time out of work explained job-seeking efforts demographic characteristics such as gender, age and ethnicity were not related to how long job-seekers sustained their job-seeking efforts. These points are also further supported by the international literature (e.g. Kulik, 2001).

\section{Table 3 Reason for becoming a mature job-seeker}

\begin{tabular}{llllll}
\hline Reason for becoming & Male & $\%$ & Female & $\%$ & Total
\end{tabular}
a job-seeker

\begin{tabular}{lrrrrrr}
\hline Compulsory redundancy & 155 & 18.0 & 68 & 7.9 & 223 & 25.9 \\
Returning from family & 63 & 7.3 & 168 & 19.5 & 231 & 26.8 \\
Voluntary redundancy & 45 & 5.2 & 33 & 3.8 & 78 & 9.1 \\
Dismissed from job & 38 & 4.4 & 12 & 1.4 & 50 & 5.8 \\
Newly arrived in NZ & 23 & 2.7 & 15 & 1.7 & 38 & 4.4 \\
Health and Disability & 22 & 2.6 & 19 & 2.1 & 40 & 4.6 \\
Lack of work and hours & 19 & 2.2 & 21 & 2.4 & 40 & 4.6 \\
Early retirement & 18 & 2.1 & 16 & 1.9 & 34 & 3.9 \\
Self employed - closed & 12 & 1.4 & 4 & .5 & 16 & 1.9 \\
Moved to new location & 11 & 1.3 & 11 & 1.3 & 22 & 2.6 \\
Want to change job & 8 & .9 & 25 & 2.8 & 32 & 3.7 \\
Other & 8 & .9 & 6 & .7 & 14 & 1.6 \\
Contract ended & 7 & .8 & 1 & .1 & 8 & 0.9 \\
Returning from study & 5 & .6 & 8 & .9 & 13 & 1.5 \\
Seeking work first time & 3 & .3 & 10 & 1.2 & 13 & 1.5 \\
Relationship ceased &. & & 9 & 1.0 & 9 & 1.0 \\
\multicolumn{1}{c}{$\quad$ Total } & $\mathbf{4 3 7}$ & $\mathbf{5 0 . 8}$ & $\mathbf{4 2 4}$ & $\mathbf{4 9 . 2}$ & $\mathbf{8 6 1}$ & $\mathbf{1 0 0 . 0}$ \\
\hline
\end{tabular}




\section{The gender variable}

Table 3 illustrates the fundamental difference between male and female respondents. The primary reason for becoming a mature job-seeker for male respondents was the experience of compulsory redundancy $(155,18$ percent); whereas for women the primary the reason for becoming a mature job-seeker was returning from family responsibilities $(168,19.5$ percent). This supports labour force participation figures showing that when the majority of most males enter the workforce (25-29 year cohort) their working life is relatively uninterrupted till the 55-59 year cohort when the first noticeable drop-off in participation occurs. Compulsory redundancy is an example of an involuntary exit from the labour force that is obviously not welcomed by the participants in the present study (primarily men) and could realistically pose real problems for such men as compared to the majority of the women whose experience of the labour force has been less secure.

In the present study respondents are asked why they became mature job seekers, which is semantically different from Perry's (2001) Australian study, which asks older workers why they left employment. Semantics aside, redundancy, in Perry's study, accounted for 23.4 percent of mature male reasons for leaving employment with males in the 50-54 age group most affected: a result very similar to this study.

In conclusion the present snapshot of results highlights three key issues: 1) that current definitions of older workers reflect the male experience of the labour market, 2) that mature job-seeking behaviour is sustained at best for six months, and 3) the reasons for becoming a jobseeker are likely to require varied policy responses.

\section{Implications}

There are urgent economic, social and demographic imperatives to address the triple jeopardy of age, work and invisibility both for older people in, and looking for, work. The question is how best to elevate issues of age and work in political and policy frameworks. Several impediments stand in the way. For example, the pervasive and ingrained nature of social stereotyping (McGregor and Gray, 2002) should not be under-estimated. And what should not be over-estimated is the cohesive nature of the age lobby. For despite the rhetoric of grey power and frequent media illusions to a demographic wave there is not a specific focus on employment and age issues nationally, despite valuable regional and community work undertaken by mature employment support agencies. Compounding the somewhat diffuse and fragmented nature of the older worker lobby is the ad hoc nature of policy responsibility which is spread across various government ministries.

It is logical that age and work should, and must, assume future policy priority. But the findings of the mature worker study show that it cannot be assumed that older workers represent a homogenous group with a one-size fits all policy approach. The profile of older female and male workers is quite different, there are significant differences between skilled and unskilled older workers and when older workers are out of a job the reasons for becoming mature job seekers vary.

Equally the youth-focussed nature of interventions in relation to unemployment and work encouragement will not necessarily transfer to mature job-seekers. The research reported here provides a stark message: mature job-seeking behaviour is sustained for around four to six months. That is the period of most return for unions, employers and government agencies who wish to retain and value older human capital.

\section{References}

Callister, P. and Rose, D. (2001). Implications of labour market change for retirement income policy. Wellington: Ministry of Social Policy.

Dalziel, L. (2001) The New Zealand positive ageing strategy. Wellington: Senior Citizens Unit, The Ministry of Social Policy.

Dalziel, L. (2001a). Positive ageing in a world of diversity. Opening address to the positive ageing forum. Wellington Law School. Wellington. Retrieved April 24, 2002, from

http://www.beehive.govt.nz/viewdocument.cfm?documen $\underline{\mathrm{tid}}=12138$

Deeks, J., Parker, J. and Ryan, R. (1994). Labour and employment relations in NewZealand (2nd ed.). Auckland: Longman Paul.

Department of Labour. (1989). Survey of long-term unemployment. Wellington: Department of Labour.

Easton, B. (1997). In stormy seas: The post-war New Zealand economy. Dunedin: University of Otago Press.

Feather, N.T. (1982). Unemployment and its psychological correlates: A study of depressive symptoms, self esteem, Protestant ethic values, attributional style and apathy. Australian Journal of Psychology, 34, 309-323.

Gill, M.A. (2002, June 22). Experienced? Do not apply. Waikato Times, p.25

Higgins, J. (1999). From welfare to workfare. In J. Boston, P. Dalziel, \& S. St John (Eds.). Redesigning the welfare state in New Zealand: Problems, policies, prospects (pp. 260-277). Auckland: Oxford University Press.

Kaufman, H.G. (1982). Professionals in search of work: Coping with the stress of job loss and 
underemployment. New York: John Wiley \& Sons Ltd.

Kelsey, J. (1999). Reclaiming the future: New Zealand and the global economy. Wellington: Bridget Williams Books.

Koopman-Boyden, P.G. (1992). New Zealand's ageing society: The implications. Wellington: Daphne Brasell Associates Press.

Kulik, L. (2001, March). Impact of length of unemployment and age of jobless men and women: A comparative analysis. Journal of Employment Counselling, 38, 15-27.

Macky, K. and Johnson, G. (2000). The strategic management of human resources in New Zealand. Auckland: McGraw-Hill.

Maharey, S. (2000a, September). Opportunity, capacity, participation: Government employment strategy 2000. Wellington: Minister of Social Services and Employment.

Maharey, S. (2000b, 1 September). Opening opportunities for older workers. Address to the AGM of the Manawatu branch of the Mature Employment Support Agency. Palmerston North. Retrieved April 24, 2002, from

http://www.beehive.govt.nz/viewdocument.cfm?documen tid $=8377$

Maharey, S. (2001, June). Pathways to opportunity: From social welfare to social development. Wellington: Office of the Minister of Social Services and Employment.

Maharey, S. (2002a, March 30-31). Cash for jobs plan targets over-40s. Weekend Herald, A5.

McGregor, J. (2001). Employment of the older worker. Palmerston North: Massey University.

McGregor, J. and Gray, L. (2001). The mature jobseeker in New Zealand. Palmerston North: Massey University.

McGregor, J. and Gray, L. (2002). Stereotypes and older workers: the New Zealand experience. Social Policy Journal of New Zealand, 18, 163177.

Ministry of Economic Development. (2000). Regional development strategy. Cabinet Briefing Paper. Wellington: Ministry of Economic Development.

http://www.med.govt.nz/pubs/publications-01.html\#rd

New Zealand Employers' Federation. (1998). A guide for employers on the employment of older workers and retirement. New Zealand Employers' Federation: Wellington.
New Zealand Institute of Economic Research. (2002). New Zealand industries and regions: Outlook and issues to 2006. Wellington: NZIER.

OECD. (2000). Reforms for an ageing society. Paris: OECD.

Perry, J. (2001, December). Too young to go: Mature age unemployment and early retirement in New South Wales. Sydney: NSW Committee on Ageing.

Rudman, R. (2000). Human resources management in New Zealand (3rd ed.). Auckland: Longman Paul.

Sayers, J. and Tremaine, M. (Eds.). (1994). The vision and the reality: Equal employment opportunities in the New Zealand workplace. Palmerston North: Dunmore Press.

Shirley, I., Easton, B., Briar, C. and Chatterjee, S. (1990). Unemployment in New Zealand. Palmerston North: Dunmore Press.

Statistics New Zealand. (1995). New Zealand now: Baby boomers. Wellington: Statistics New Zealand.

Statistics New Zealand. (2000). Key statistics: Population ageing in New Zealand. Wellington: Statistics New Zealand.

Statistics New Zealand. (2002). Labour Market Statistics - 2001. Wellington: Statistics New Zealand.

Stephenson, J., and Scobie, G. (2002, March). The economics of population ageing. New Zealand Treasury Working Paper 02/05. Wellington: New Zealand Treasury.

The Royal Commission on Social Policy. (1988). The April Report: Future Directions Vol II. Wellington: The Royal Commission on Social Policy.

Thomson, D. (1998). Old age in the new world: New Zealand's colonial welfare experiment. In $\mathrm{P}$. Johnson and P. Thane (Eds.), Old age from antiquity to post-modernity (pp.146-179). London: Routledge.

Treasury. (2001, July). Towards an inclusive economy. Treasury Working Paper 01/15.Wellington: New Zealand Treasury.

Tweedy, R. and Johnson, K. (1996). Mature employment and post-modern portfolio living. In P.S. Morrison (Ed.), Proceedings of the Seventh Conference: Labour, Employment and Work in New Zealand (pp.141-147). Wellington: Victoria University.

Warr, P.B. and Jackson, P. (1984). Men without jobs: Some correlates of age and length of 
unemployment. Journal of Occupational Psychology, 57, 77-85.

Warr, P. (1994). Age and Employment. In H.C. Triandis, M.D. Dunnette, and L.M. Hough (Eds.), Handbook of Industrial and Organizational
Psychology (pp.485- 550) Palo Alto: Consulting Psychologists Press Inc.
Watkin, T. (2002 March 30-31). On the scrap heap. Weekend Herald, p.G3. 